\title{
Fluoride content in well waters for human and animal consumption with reported high incidence levels of endemic fluorosis in Beni Meskine (Morocco)
}

\author{
Hanane Maadid $^{1,2}$ (D) El Houssine El Mzouri ${ }^{1} \cdot$ Achraf Mabrouk $^{3}$ • \\ Yahya Koulali ${ }^{2}$
}

Received: 14 September 2016/Accepted: 6 June 2017/Published online: 20 June 2017

(c) Springer International Publishing AG 2017

\begin{abstract}
Groundwater is widely used as a source of drinking water in many rural areas of Morocco. Among those areas, there is Beni Meskine that is known for its residents' high fluoride intake through drinking water. Many symptoms such as dental caries, teeth and skeletal effects are frequent and pronounced in this rural population. The objective of this study is to determine fluoride content in groundwater consumed by the local population and animals. A total of 152 samples were collected at different groundwater depths, and they were analyzed for fluoride, $\mathrm{pH}$, and electrical conductivity. The concentrations of fluoride obtained by ion selective electrodes were in a range from 0.61 to $3 \mathrm{mg} / \mathrm{L}$, and the highest values were attained in the plateau area of Beni Meskine, that is already known for its high fluoride concentrations. This part of the country is richer in phosphate rock compared to other regions. Fluoride content in drinking water varied with the wells' depth: samples from wells deeper than $80 \mathrm{~m}$ show fluoride concentrations lower than the standard recommended by WHO, but the deeper the water in the wells, the higher the fluoride content. Fluoride levels in the groundwater were positively correlated with conductivity but negatively related to the water depth. In conclusion, the occurrence of fluorosis in human and animals may be
\end{abstract}

Hanane Maadid

maadid.hanane@gmail.com

1 Agronomy Department, Regional Center for Agricultural Research (INRA), Settat, Morocco

2 Laboratory of Ecodesign, Energy, Environment and Innovation, University Hassan 1st, Settat, Morocco

3 Laboratory for Food and Health, University Hassan 1st, Settat, Morocco reduced if the drinking water in rural areas is extracted from a depth in a water table of more than $80 \mathrm{~m}$ deep.

Keywords Groundwater · Well water · Fluorosis · Fluoride - Beni Meskine · Morocco

\section{Introduction}

Groundwater is the main source of water in many dryland areas of Morocco. Such water is the essential component for sustaining life and the environment. The presence of various hazardous contaminants like fluoride in underground water has been reported from different regions in the world and particularly in Morocco (Khouribga and Safi) (Abdennebi et al. 1995; Haikel et al. 1989). Water fluoride concentration depends on many factors such as the size and the type of geological formation through which ground water is circulating, $\mathrm{pH}$, temperature, and solubility. Fluoride concentration in seawater averages $1.3 \mathrm{mg} / \mathrm{L}$, while in fresh water supplies, the natural range is between 0.01 and $0.3 \mathrm{mg} / \mathrm{L}$. Groundwater recharge takes place by direct infiltration of rainfall and to a lesser extent from influent streams and rivers. Several efforts have been made to improve the availability of drinking water in Morocco, though part of the population still uses water wells provided for domestic purposes, whose quality is unknown. The WHO established a maximum acceptable concentration of $1.5 \mathrm{mg} / \mathrm{L}$ for fluoride in drinking water (WHO 2004). The adequate intake for fluoride from all sources is set at $0.05 \mathrm{mg} / \mathrm{day} / \mathrm{kg}$ body weight; this intake is recommended for all ages greater than 6 months (WHO 1997).

The principal sources of fluoride to man and animals are drinking water, vegetation grown on fluorotic soils, dust in air, and certain industrial processes (Sompura 1997). 
Fluoride was found naturally in many minerals in the environment, particularly in fluorspar, apatite, mica rock phosphate and cryolite that have commercial importance (Murray 1986). Fluoride is an essential oligo-element to normal mineralization of bones and formation of dental enamel. However, at high doses, fluoride cause intoxication as a chronic manifestation in bone, kidney, the nervous system and especially in dental processes. Dental fluorosis is a lesion of hard tissue due to excessive intake of fluoride during the mineralization of the crowns of the teeth characterized by caries; teeth display brown to black staining and discoloration or opacity around the edges during the tooth calcification (Dean 1938). Skeletal fluorosis can also be observed after prolonged ingestion of high amounts of fluoride, which can cause pain, and damage to bones and joints. In the worst case, other signs include rigidity of the vertebral column, impairment of articular movements and calcification of ligaments and tendons (Brower et al. 1988).

According to the local population of Beni Meskine, more than $70 \%$ of residents as well as animals use well water, which is regarded as the main daily contributor to fluoride intake (Maadid et al. 2016). Livestock suffers from fluorosis that cause an important economic damage for the local farmers. This study aimed to analyze the groundwater fluoride content of different well depths and that used for drinking water in rural areas of Beni Meskine territory by using a fluoride selective electrode.

\section{Materials and methods}

\section{Profile of the study area}

Beni Meskine is one of the dryland areas of the North-West of Morocco (Fig. 1), which is composed of 12 communal divisions. It has an area of about $2000 \mathrm{~km}^{2}$, between the longitude $32^{\circ} \mathrm{N}$, and latitude $7^{\circ} \mathrm{S}$, and an altitude that varies between 300 and $500 \mathrm{~m}$. A total population of about 120,000 inhabitants and about more than two million heads of sheep with a few thousand cattle, donkeys, and goats suffer from fluorosis. This high fluoride content in this part of Morocco is highly related to the geological structure that encloses high phosphate mining in the future. Groundwater consumption in this area increases particularly in the summer season, where heat exceeds $40{ }^{\circ} \mathrm{C}$. Fluorosis causes a great economic damage to sheepherders because of teeth loss and affects negatively sheep performance.

\section{Sample collection}

A total of 152 water samples were collected, and the sampling took place in the period between October and November 2014 using a GPS "Global Positioning System" of Garmin with an accuracy of $2.9 \mathrm{~m}$. Each sampling point had geographical coordinates (North, West) and was projected by the ArcGIS software on the map of Beni Meskine (Fig. 1).

For each sample, a volume of $500 \mathrm{~mL}$ was collected in clean and sterile polyethylene bottles and stored in an icebox at $4{ }^{\circ} \mathrm{C}$ for laboratory analysis. Field measurements was made for $\mathrm{pH}$, electrical conductivity, and fluoride.

\section{Laboratory analysis}

All measurements were made at $25^{\circ} \mathrm{C}$ by a fluoride portable meter (model HI 98402) with a specific ion electrode $\mathrm{F}$ combined with a reference electrode $(\mathrm{Ag} / \mathrm{AgCl})$. This method can be used for measuring total solubilized fluoride in drinking water. The advantage of this method is its simplicity and speed of response in a wide range of concentrations of fluoride ion with an error of $\pm 5 \%$. Sodium fluoride (NaF) was used to prepare standard solutions (1000 mg/L F) and $(100 \mathrm{mg} / \mathrm{L} \mathrm{F})$. Standards and samples were mixed 1:1 with a total ionic strength adjustment buffer (TISAB). The method detection limit is $0.5 \mathrm{mg} / \mathrm{L}$. Fluoride concentrations from 0.025 to $500 \mathrm{mg} / \mathrm{L}$ may be measured. Each sample was analyzed three times. A HANNA pH $211 \mathrm{~m}$ and a conductivity BRIDGE Model 31 measured the $\mathrm{pH}$ and electrical conductivity, respectively.

\section{Statistics}

One-way analysis of variance (ANOVA) and the Pearsontest were used to obtain statistical analysis regarding the fluoride level in water in different areas. Differences were considered statistically significant when the $p$ value was 0.05 .

\section{Results}

The groundwater had no color, odor and turbidity at most of the locations. Taste of the water was fresh to slightly salty. The results of chemical analysis are listed in Table 2.

Fluoride The concentration of $\mathrm{F}$ ranged from 0.61 to $3 \mathrm{mg} / \mathrm{L}$ with an average of $1.51 \mathrm{mg} / \mathrm{L}$ in the study area (Table 2). At most of the locations, fluoride concentration was higher than the permissible limit with drinking water standards (Moroccan and WHO). Whereas, some samples were within the permissible limit.

The fluoride content varied with the source location. The analysis highlights that $5 \%$ of wells had fluoride content lower than $0.7 \mathrm{mg} / \mathrm{L}$, whereas $20 \%$ contained between 0.7 and $1 \mathrm{mg} / \mathrm{L}$. In addition, $33 \%$ of wells had a content between 1 and $1.5 \mathrm{mg} / \mathrm{L}$, and, finally, $42 \%$ represented the samples higher than $1.5 \mathrm{mg} / \mathrm{L}$. The results are displayed in Fig. 2 and on the map of Beni Meskine (Figs. 3, 4). 


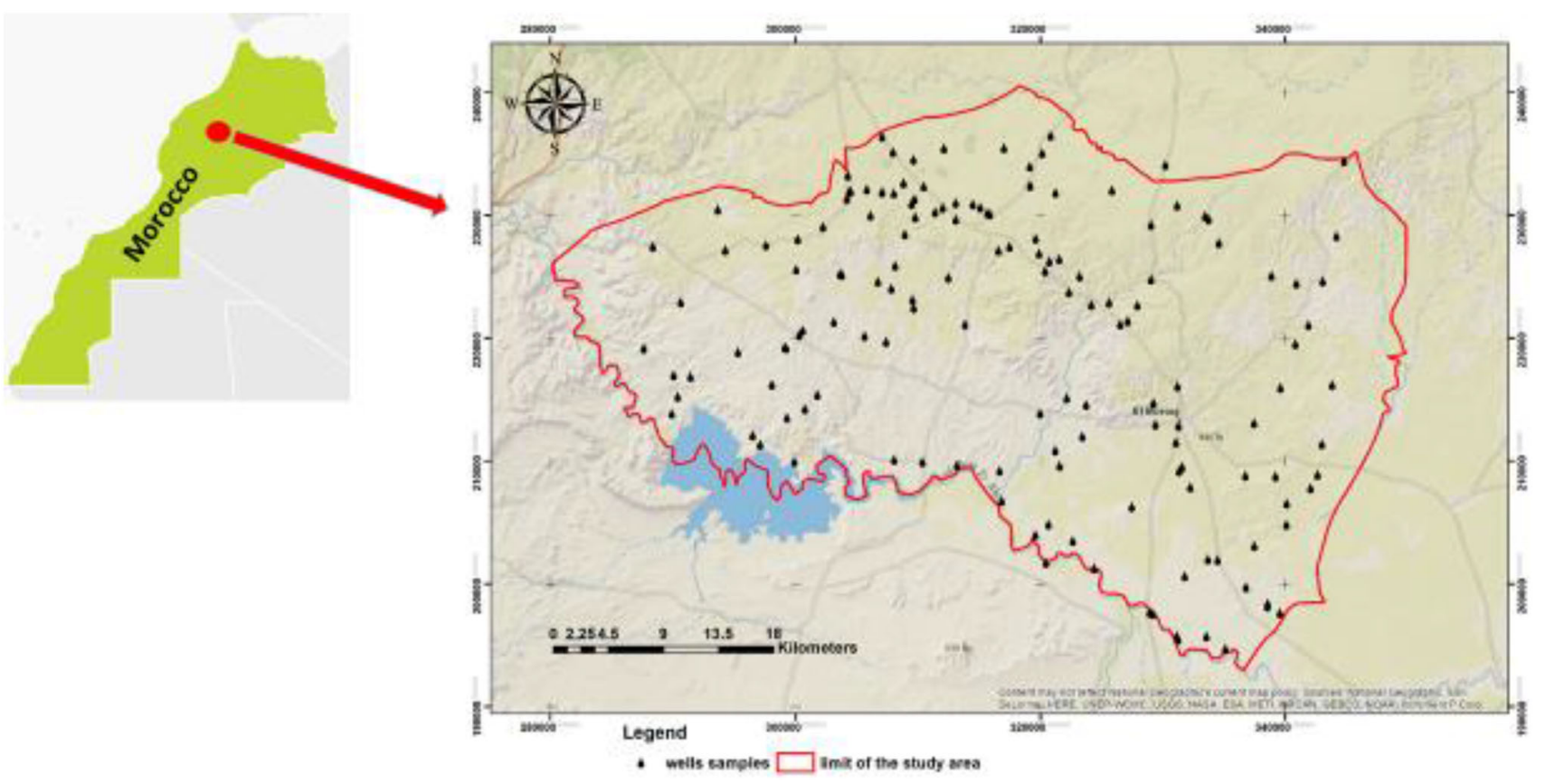

Fig. 1 The study area of Beni Meskine, a plateau located in Central Western Morocco

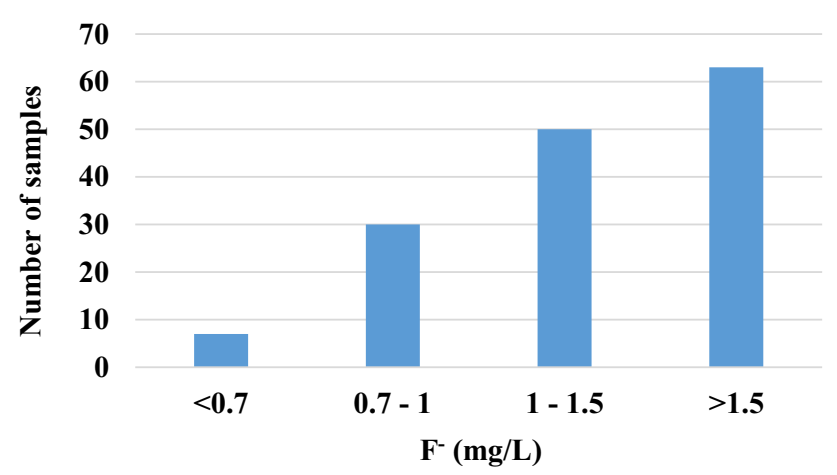

Fig. 2 Frequencies of fluoride concentration in well water

The analysis of variance showed a statistically significant difference $(p \leq 0.05)$ between the measured potential values corresponding to the different parameters analyzed $(\mathrm{pH}$, fluoride, and electrical conductivity). We used after ANOVA, the Pearson correlation test to prove how well one variable predicts the other. The correlation coefficient is a usually used measure to establish the relationship between two quantitative variables; the results are given in Table 1 .

The correlation showed that fluoride displayed good positive correlations $(\rho=0.34)$ with conductivity and negative correlation with depth $(\rho=-0.43)$. However, there is no correlation between $\mathrm{pH}$ with depth, fluoride and conductivity. According to the negative correlation between depth and fluoride, it indicates that as depth variable increases, the other fluoride variable decreases. Based on this data, the first remark that seems interesting, it that wells with a depth over $80 \mathrm{~m}$ have fluoride concentrations less than $1 \mathrm{mg} / \mathrm{L}$.

$\mathrm{pH}$ The $\mathrm{pH}$ values of the groundwater samples ranged from 6.68 to 8.43 with an average of 7.7 (Table 2). This shows that the groundwater of the study area is mainly alkaline. According to the WHO, The safe limit of the $\mathrm{pH}$ lies between 6.5 and 8.5. The results indicate that the samples are within the permissible limit and do not cause any problem for human consumption. Furthermore, $\mathrm{pH}$ exhibits no significant correlation with any one of the depths $(\rho=-0.01)$, fluoride $(\rho=0.08)$ or electrical conductivity $(\rho=0.13)$.

Electrical conductivity (EC) The average is $1450 \mu \mathrm{S} / \mathrm{cm}$ with extremes between 270 and $4130 \mu \mathrm{S} / \mathrm{cm}$ (Table 2). The World Health Organization adopted the electrical conductivity between 450 and $1500 \mu \mathrm{S} / \mathrm{cm}$. Hence, $35 \%$ of samples were not within the permissible limit of electrical conductivity. Higher values were generally noticed in the northeastern area (phosphate area).

\section{Discussion}

The $\mathrm{pH}$ of the samples $(6.68-8.43)$ is not exceeding 8.5 which is the permissible limit recommended for drinking water according to the WHO (WHO 2000). Results in the laboratory indicated that alkaline $\mathrm{pH}(7.6-8.6)$ is favorable for fluoride dissolution to groundwater from fluoride minerals (Saxena and Ahmed 2001). Thermal waters of high $\mathrm{pH}$ are also rich in fluoride (Edmunds and Smedley 1996). 


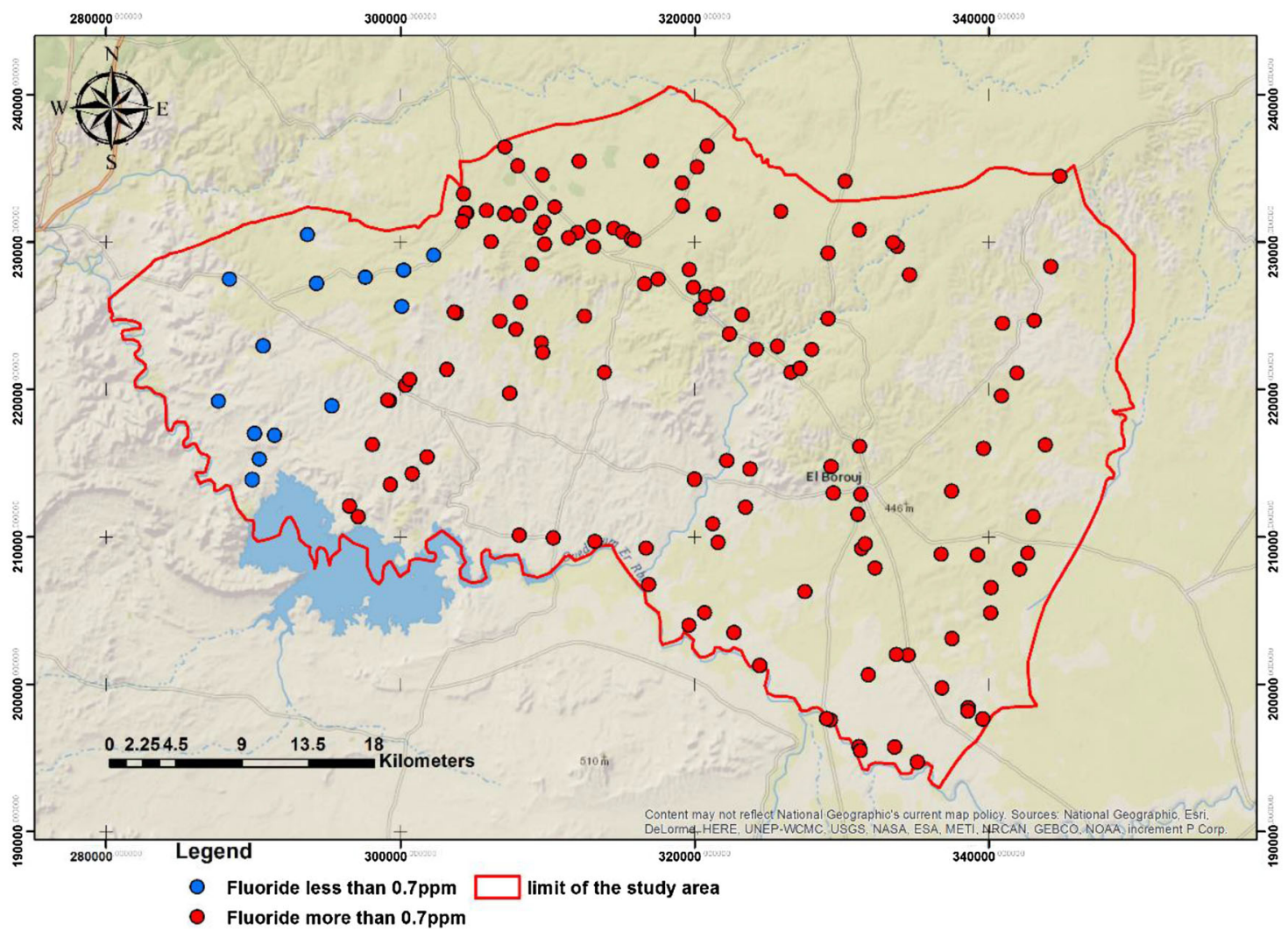

Fig. 3 Groundwater fluoride content in Beni Meskine territory according to the Moroccan Health Ministry Standards (the highest permissible limit of $\mathrm{F}^{-} 0.7 \mathrm{mg} / \mathrm{L}$ )

The majority of well water samples (95\%) exceeded the standard limit used in Morocco (0.7 mg/L) (SGG 2002), while $42 \%$ exceeded the permissible limit set by the WHO $(1.5 \mathrm{mg} / \mathrm{L})$. In addition, the analysis highlights that for the water, which presents the highest content of fluoride $(>1 \mathrm{mg} / \mathrm{L})$, there are consequently the areas where fluorosis has the most widespread pathology. Host rock containing fluoride minerals may explain the anomalously high concentrations in groundwater (Wenzel and Blum) Wenzel and Blum 1992.

Dental fluorosis was found in the area where the fluoride concentration in the drinking water was $1 \mathrm{mg} / \mathrm{L}$. This study shows that the recommended upper limit of $1.5 \mathrm{mg} / \mathrm{L} \mathrm{flu}-$ oride in the drinking water is not suitable to prevent dental fluorosis in Beni Meskine. If we consider that the water consumption per adult per day is $2 \mathrm{~L}$, the fluoride ingested dose is $0.09 \mathrm{mg} / \mathrm{kg} / \mathrm{day}$ in the area; the water has $3 \mathrm{mg} / \mathrm{L}$ of fluoride. this value of ADI (acceptable daily dose) exceeds the safety limit set by the WHO, which is $0.05 \mathrm{mg} / \mathrm{kg} /$ day (WHO 2011). Fluorosis is related to the ecology of this region whose inhabitants have a special land and lifestyle; the hot and arid climate leads to high water consumption and accumulation of fluoride in the body. Fluoride can be provided also by food such as tea, dates and green vegetables (Galagan and Lamson 1953).
In Morocco, few studies examining the fluoride content in natural matrices and fluorosis were published. According to previous investigations, some work found high concentrations of fluoride in water $(1.6 \mathrm{mg} / \mathrm{L})$ in Safi (Kessabi et al. 1984), whereas, the highest value in Khouribga was $1.15 \mathrm{mg} / \mathrm{L}$ (Haikel et al. 1986).

In Nigeria, studies have revealed that a prevalence of $51 \%$ for a rate of $0.1-0.4 \mathrm{mg} / \mathrm{L}$ of fluoride in water (ElNadeef and Honkala 1998; Wenzel and Blum 1992) and Tanzania; one study has been reported of severe dental lesions with fluoride concentrations of $0.4 \mathrm{mg} / \mathrm{L}$ (Mabelya et al. 1992).

Our study shows that with a content of $3 \mathrm{mg} / \mathrm{L}$, prevalence of fluorosis is $100 \%$ in Beni Meskine. This may explain that fluorosis depends not only on the fluoride content in drinking water but also on so many factors like nutritional status (Malde et al. 2011) weather (Brower et al. 1988b) and altitude (Murray and Wilson 1948).

\section{Conclusion}

This study managed to sketch a map of fluoride content in well waters in the region of Beni Meskine, thus allowing assessing the concentration of fluoride in the main source 


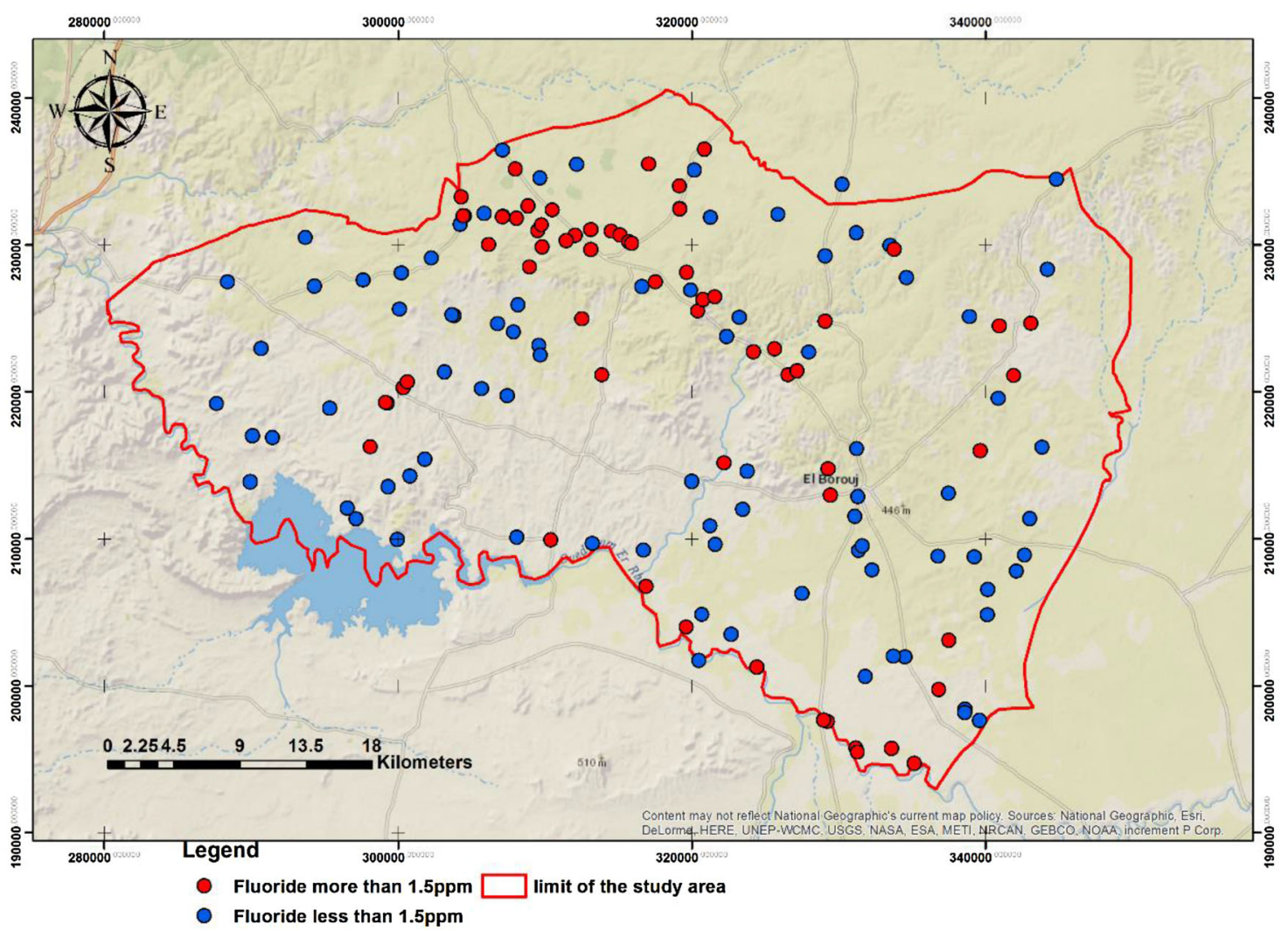

Fig. 4 Groundwater fluoride content in Beni Meskine territory according to the WHO (the highest permissible limit of $\mathrm{F}^{-} 1.5 \mathrm{mg} / \mathrm{L}$ )

Table 1 Pearson correlation coefficient between fluoride and other parameters (conductivity, depth and $\mathrm{pH}$ )

\begin{tabular}{llcc}
\hline Variables & & $\rho$ of Spearman & Prob. $>|\rho|$ \\
\hline Fluoride & Depth & -0.43 & $<0.001^{*}$ \\
Conductivity & Depth & -0.15 & 0.07 \\
Conductivity & Fluoride & 0.34 & $<0.001^{*}$ \\
$\mathrm{pH}$ & Depth & -0.01 & 0.90 \\
$\mathrm{pH}$ & Fluoride & 0.08 & 0.31 \\
$\mathrm{pH}$ & Conductivity & 0.13 & 0.08
\end{tabular}

* Significant correlation

Table 2 Mean and range of Conductivity $(\mu \mathrm{S} / \mathrm{cm}), \mathrm{F}^{-}(\mathrm{mg} / \mathrm{L})$, and $\mathrm{pH}$ for all tested samples

\begin{tabular}{ll}
\hline Chemical parameters & All data $(n=152)$ \\
\hline $\mathrm{F}^{-}$ & $1.51(0.61-3 \mathrm{mg} / \mathrm{L})$ \\
$\mathrm{pH}$ & $7.55(6.68-8.43)$ \\
Conductivity & $1450(270-4130 \mu \mathrm{S} / \mathrm{cm})$ \\
\hline
\end{tabular}

of drinking water for the local population and livestock. Such water is out of control, and exposes the locals to several health risks, including dental and skeletal fluorosis, namely in the case of high levels of fluoride in the phosphate area. Such health risks should be taken into account for imposing emergency measures of defluoridation of water abstracted from wells in the region of Beni Meskine.

Acknowledgements We knowledge and recognize INRA and the Ovine Sardi Chain value valorization project for the financial and the scientific support to realize this work.

\section{Compliance with ethical standards}

Conflicts of interest The authors declare no conflict of interest.

\section{References}

Abdennebi EH, Fandi R, Lamnaouer D (1995) Human fluorosis in Morocco: analytical and clinical investigations. Vet Hum Toxicol 37:465-468

Brouwer ID, De Bruin A, Dirks OB, Hautvast JGAJ (1988) Unsuitability of world health organisation guidelines for fluoride concentrations in drinking water in Senegal. Lancet 331(8579):223-225. doi:10.1016/S0140-6736(88)91073-2

Dean HT (1938) Endemic fluorosis and its relation to dental caries. Public Health Reports 53(33):1443-1498. doi:10.1525/jer.2012.7.1.51

Galagan DJ, Lamson GG (1953) Climate and endemic dental fluorosis. Public Health Rep 68(5):497-508

Edmunds WM, Smedley PL (1996) Groundwater geochemistry and health: an overview. Geol Soc Lond Spec Publ 375:261-267

El-Nadeef MA, Honkala E (1998) Fluorosis in relation to fluoride levels in water in central Nigeria. Community Dent Oral Epidemiol 2:26-30 
Haikel Y, Voegel JC, Frank RM (1986) Fluoride content of water, dust, soils and cereals in the endemic dental fluorosis area of Khouribga (Morocco). Arch Oral Biol 31(5):279-286

Haikel Y, Cahen PM, Turlot JC, Frank RM (1989) Dental caries and fluorosis in children from high and low fluoride areas of Morocco. ASDC J Dent Child 56:378-381

Kessabi M, Assimi B, Braun JP (1984) The effect of fluoride on animals and plants in the south Safi zone. Sci Total Environ 38:63-68

Maadid H, Koulali Y, Mabrouk A, El Mzouri E (2016) Exploitation of local knowledge of farmers on fluorosis for mapping soil in morocco western central: case of Beni Meskine, province of Settat. Int J Adv Res. ISSN No. 2320-5407

Mabelya L, König K, Van Palensteinhelderman WH (1992) Dental fluorosis, altitude and associated dietary factors. Caries Res 26:65-67

Malde MK, Scheidegger R, Julshamn K, Bader HP (2011) Substance flow analysis: a case study of fluoride exposure through food and beverages in young children living in Ethiopia. Environ Health Perspect 119:579-584

Murray JJ (ed) (1986) Appropriate use of fluorides for human health. World Health Organization, Geneva

Murray MM, Wilson DC (1948) Fluorosis and nutrition in Morocco. Dental studies in relation to environment. Br Dent J 84:97-100
Saxena V, Ahmed S (2001) Dissolution of fluoride in groundwater: a water-rock interaction study. Environ Geol 40(9):1084-1087

SGG 2002. Moroccan Standards. Moroccan Guidelines for Drinkingwater Quality [online]. Official Bulletin No. 5062. http://www. sgg.gov.ma/BOlbulletin|Fr|2002\BO_5062_fr.PDF. Accessed 15 June 2013

Sompura K (1997) Study on prevalence and severity of chronic fluoride intoxication in relation to certain determinants of fluorosis. PhD thesis, Mohanlal Sukhadia University, Udaipur, Rajasthan

Wenzel WW, Blum WE (1992) Fluoride speciation and mobility in fluoride contaminated soil and minerals. Soil Sci 153:357-364

World Health Organization (2000) Quality guidelines for drinking water. In:Hygiene criteria and supporting documentation, vol 2, 2nd edn. p 1050

World Health Organization (2011) Guidelines for drinking-water quality, 4th edn. WHO, Geneva

World Health Organization (WHO) (1997) Guideline for drinking water quality, vol 3. Surveillance and control of community supplies, Geneva

World Health Organization (WHO) (2004) Guidelines for drinkingwater quality recommendation, 3rd edn. WHO, Geneva 